\title{
The Salpinx in Greek Cult
}

The salpin $x^{1}$ is not often treated by scholars of ancient Greek music, because it was mainly a military instrument. As West (1992: 118) says: "It is by courtesy only that we give attention to this instrument, as it was not used for musical purposes, but only for giving signals...".

Trumpets were found in West Asia at least from the $16^{\text {th }}$ century BC (Duchesne-Guillemin 1981; Hickman 1946). In Egypt the earliest certain representations appear in the $15^{\text {th }}$ century $\mathrm{BC}$ in the reliefs in the temple of Hatshepsut at Deir el-Bahari, and two trumpets, one of silver and the other of bronze, were found in the grave of Tutankhamun. ${ }^{2}$ In Greece the salpinx is known from the $8^{\text {th }}$ century onwards. In Greek antiquity the instrument was often considered to be an Etruscan invention, but it is organologically now usually compared to the Egyptian trumpet (West 1992: 119).

The Greek salpinx was an aerophone, usually made of bronze, and consisted of an 80 to $120 \mathrm{~cm}$ long, straight, tube with cylindrical bore, and with a conical or more often bell-shaped final, kodon, which could be made of bone (West 1992: 118), see Fig. 1. The bone had to be fired in order to get the right acoustic qualities, according to Aristotle (De aud. 208a-b).

Salpinx is usually translated as "trumpet", but the type of sound generator it may have had has been discussed. Was it a reed instrument, such as a medieval bombard, or did it have a mouth generator similar to the modern trumpets? (Paquette 1984: 74; Krenz 1991; Bélis 1986: 212-217). The sound generator is not mentioned by contemporary authors, but Pollux (4.85) in the $2^{\text {nd }}$ century $\mathrm{AD}$ seems to describe a reed instrument. Vase paintings show that the salpinx was sometimes played with the phorbeia, the mouth band typical of the reed instrument aulos, see the kylix by Epiktetos, Fig. 1. The story of trumpeters, such as Molokron, who was trum-

\footnotetext{
${ }^{1}$ A wind instrument of bone and shell also existed. Arist. De audib. 208a-b; West 1992: 121.

${ }^{2}$ The longer silver trumpet measured $0.582 \mathrm{~m}$, and the shorter bronze instrument 0.492 m. Hickmann 1961: 120; Manniche 1991: 75-80, pl. 14.
} 
peter to Ptolemaios Philipator and who could play two salpinges at the same time (Pollux IV.88), can also be taken to indicate reed instruments. ${ }^{3}$ Against this it has been argued that late sources, such as Pollux, cannot be used as evidence for earlier Greek periods, that the phorbeia may have functioned differently for salpinges and auloi, and that a reed instrument would be unsuitable for military purposes (Krenz 1991: 112). The few ancient illustrations that depict the sound generator of the salpinx show no sign of a reed (Bélis 1986: 214) and the terracotta trumpets found on e.g. Cyprus end in a straight tube. In this paper the translation "trumpet" will be used, without prejudice.

The trumpet lacked holes or valves, which meant that only the natural notes could be played, probably only two or three notes. ${ }^{4}$ The descriptions of its sound emphasize the loudness: The sound is described as shrill or penetrating (Aisch., Eumen 567-68), and it is compared to the great war cry of Achilles (Il. 18.219), the clash of the gods on the battle field (Il. 21.388), trumpeting elephants (Arist., Hist. Anim. 536b) or the braying of donkeys.

The descriptions of the trumpeters stress their heroic aspects. Epistades could make his trumpet sound over 50 stadia or almost $9 \mathrm{~km}$ (Pollux 4.88), and Herodoros from Megara, who slept on a bear skin and dressed in a lion skin, with an appetite to match, won seventeen victories in trumpet playing (Ath. 414f-415a) and could play so loud that it was difficult to be near him when he was playing (Pollux 4.88-89). Herakles was the obvious role model for these musicians (although as far as I know, there are no depictions of Herakles as a salpinx-player). It is therefore often thought that salpinx-playing was a question mainly of blowing loud and long. But it seems as if the musicians might sometimes use tonguing to play fanfares. A painting on an epinetron from Eleusis shows a trumpeting Amazon blowing fanfares, rendered as "Tote Totote" (Bélis 1984: figs. 1-3). An an-

\footnotetext{
${ }^{3}$ Other evidence brought into the discussion are the instruments found in Pompeii: three cornuu, a straight trumpet, $t u b a$, with a mouth generator and two with reed generators. Bélis 1986: 217.

${ }^{4}$ The shorter of the trumpets from the grave of Tutankhamun has been played on at least three occasions (Manniche 1991: 76 f.). At a test in 1939 three notes were played with a modern mouthpiece. In its original state, i.e. without mouthpiece, it was possible to play two notes, one between $\mathrm{C}$ and $\mathrm{C}^{\#}$ and the other close to $\mathrm{E}^{2}$ in a later test. The sound is described as "rich and powerful" (Manniche 1991: 77). It is likely that the ancient trumpeters in practice used a much smaller range of notes than what is theoretically possible with the right mouthpiece.

${ }^{5}$ Epinetron by the Sappho Painter (Eleusis inv. 907), c. 500 BC (Haspels 1936: 228, no. 54, pl. 34; Lissarague 1990: 127, fig. 97; also discussed by Bélis 1984). It can be noted
} 
ecdote told by Plutarch (Mor. 973B-E) concerns a Roman jay, known for its skill in imitating sounds. This bird was so shocked by the loud trumpet signals from a funeral procession passing by that it became totally dumb. But after a period of meditation the jay once again started to make sounds, namely a perfect imitation of the music of the trumpets, "their tunes with all their punctuations, modulations, and note-patterns" (West 1992: 120). Although this anecdote belongs to the Roman period, it still indicates that one should not imagine the salpinx signal as being only monotonous.

The trumpet's military function is discussed by the ancient military authors and has recently been treated by Krenz (1991). It can be described as a call to arms (Aeneas Tact. 27,4), a signal for reveille, silence, to charge and to break camp (Ath. 415a); that is, the trumpet signals the change of one state to another. It was also used to coordinate efforts when hauling along siege machines, as Athenaios (415a) tells us. The trumpet signals induced fear and terror: they could frighten a town to defeat, says Onasander in The general $(42,17)$ from the $1^{\text {st }}$ century $\mathrm{BC}$, or scare away a shoal of whales, as in an episode from the age of Alexander (Diod. 17.106.7; Arrian., Indica 30.4-6; Curtius Rufus 10.1.11-12).

As a military instrument the salpinx is mentioned by Homer and as such it appears on early vase paintings, such as the Aristhonotos krater from the $7^{\text {th }}$ century B.C. ${ }^{6}$ During the Classical period trumpeters were employed in the army, at the strategic staff, as well as in the infantry, the cavalry and in the navy, as told by Xenophon (Equ. mag. 3.12; An. 4.2.29; Hell. V.19) and Thukydides (6.69). ${ }^{7}$ Its status as a military instrument can be seen from the reaction of the salpinx-makers in Aristophanes' Lysistrate (1240), when, as parts of the military industry, they see their existence threatened by the peace lovers.

In the vase paintings the trumpet is found in the hands of amazons, but also of archers and hoplites, as on the Oltos cup in Berlin, Fig. $2{ }^{8}$ In other words, it appears in both a clearly mythical and a more "realistic" sphere.

that the same rhythmic figure is given as a trumpet fanfare by Ennius (Ann 451) - but in Latin: "Tara taranta".

${ }^{6}$ Rome, Mus. Cap. no, 172, mid-7th century BC. CVA Rome Cap. Mus. 2, pl. 9 (II) (I) = Italia 39, tav. 1737; Paquette 1984: 74 f. no. T8.

${ }^{7}$ In the Hellenistic/Roman period trumpeters were attached to every taxis (company), later syntaxiarchia (battalion) of hoplites and light infantry (Asclep. Tact. 2.9; 6.3; Diod. 16.84.3; Plut. Phoc. 15). For the use of the trumpet at the navy battle at Salamis, see Aischylos (Pers. 396; cf. Diod. 20.51.2). Cf. Krenz 1991: 116, who also lists other cases.

${ }^{8}$ Red-figured kylix, Berlin F2264 by Oltos, c. 510 BC. ARV ${ }^{2}$ 60:64; CVA Berlin 1, Taf. 1, $3=$ DDR 1, Taf. 112, 114 . 
As a war symbol trumpeters were also used as shield marks. The trumpet was, however, not the only military instrument. Auloi, the Greek shawm or oboe, was often used as such, but it was the trumpet that more than any other instrument symbolised warfare.

But the trumpeters at the strategs' staff also had civic functions. Herold's signals in combination with trumpet playing are mentioned already by Bachylides (17.3-4) in the $6^{\text {th }}$ century $\mathrm{BC}$, and it was together with heralds that the first games for trumpeters were arranged in $6^{\text {th }}$ century Boiotia (Frei 1900: 65). From 396 BC or the $96^{\text {th }}$ Olympiad trumpet games were held in Olympia, ${ }^{9}$ and from the end of the $4^{\text {th }}$ century games for trumpeters also at most other major games, e.g. Nemea and Isthmia (Frei 1900: 66).

During the athletic games trumpets were used to give the starting signal for the events, especially horse races (Soph., El. 688, 711). On a blackfigured lid a trumpeter is playing while the chariot teams run around the vase, ${ }^{10}$ and a starting device at the hippodrome in Olympia incorporating trumpets is described by Pausanias (6.20.10-19). In another anecdote, also told by Pausanias (6.13.9), a horse was frightened by the trumpet signalling the last lap and threw its rider, but since it still finished first, was declared the winner. In the theatre it was used to signal the acts during the dramatic performances, since the comedy actor Hermon some time during the $2^{\text {nd }}$ part of the $4^{\text {th }}$ century BC had missed his entry because he did not hear the shout of the herald, according to Pollux (IV.88).

Aeschylos (Eum. 566-570) lets the trumpet signals sound at the meeting of the assembly. 'They were blown as an alarm when enemies threatened the city, as when the Macedonians came close to Athens in the autumn of $339 \mathrm{BC},{ }^{11}$ as told by Demosthenes (De cor. 169.1) or in connection with natural disasters, for example at the earthquake in Sparta 465 BC (Plut. Kimon 16.5-6; Polyain. 1.41.3). ${ }^{12}$

A trumpeter belonged to the pylores, the gate-keepers of the Acropolis in Athens. $\mathrm{He}$ is in a source from the Augustean period, cited by Athenaios (3.99), called the "public rooster (koinon alektoron) of Athens", and his job

\footnotetext{
${ }^{9}$ According to Eusebius (Chron ad Ol. 96 [446-32]). The winner was a certain Timaios from Elis. (Stephanis 1988: no. 2410). On the trumpeters from Olympia, see Eckstein 1988.

${ }^{10}$ Black-figured pyxis lid, Paris, Bibl. Nat. inv. 182. Ridder 1902: 90, fig. 9.

${ }^{11}$ Cf. also Diodoros (16.84.3). A similar event is recorded for $415 \mathrm{BC}$ (Andokides 1.45).

${ }^{12}$ As pointed out by Krenz (1991: 114, n. 13), this disproves the opinion that the Spartans did not use the salpinx. Cf. Xen. Hell. 5.1.9; Plut. Mor. 220E.
} 
was to give asignal over the city when the gates to the Acropolis were opened in the morning and closed at night (Geagan 1967: 125-127, 177).

But this paper is going to concentrate on the function of the trumpet in cult. Especially during the Roman period, the istrument came to be considered as a typical altar instrument. Its twin role, as the instrument of war and of peaceful cult, is stressed in e.g. epigrams in Anthologia Palatina. But did it function in this way already during the Classical period and, in that case, in what cults?

Music was an integral part of the Greek cult, espcially vocal music in choral singing and dancing. But instruments were also used. Only a few cults, usually of a chthonic character, forbade music. ${ }^{13}$ The most common cultic instruments were the auloi, which were used in both processions and at sacrifices, and are mentioned in a number of cult regulations. The auloi were so closely connected with Greek cult that Herodotos (1.132) saw it as necessary to comment upon the lack of them in the Persian cult. Lyres, usually the large kithara, seem to have belonged to processions and as instruments for accompanying choral singing, but are not depicted in connection with the sacrifice itself (Nordquist 1992). Both auloi and lyres were also played in musical games. Percussion instruments of various types were found in oriental and orgiastic cults, to gods like Dionysos, Kybele and Isis. But what functions did a typical military instrument, such as the $\operatorname{salpin} x$, have in the cult?

In the sources from the Classical period the trumpet is often mentioned in cults that have some military connections, for example at the offical rituals when the Athenian fleet departed for its fateful mission to Sicily in $415 \mathrm{BC}$ (Thuk. 6.32.1). An inscription from Gortyn on Crete from the $4^{\text {th }}$ or $3^{\text {rd }}$ century BC also mentions the salpinx in what seems to be rituals at the departure of the navy (Guarducci 1942: 185 f.). It also appears in hero cults, such as that at Plataiai to the fallen Greek soldiers, as described by Thukydides (3.58.4) and Plutarch (Arist. 21.1f.): The procession to the herograve was led by a trumpeter giving war signals, appropriate enough for a ritual to war heroes. After him followed the procession with a wagon with myrtle and wreaths, a black bull as sacrifice (Nilsson 1906: $455 \mathrm{f}$; Nilsson 1916: 312; Eitrem 1920: 68; Haldane 1966: 101). Another example are the trumpeters that were competing in the Herakles festival at Thebes in an episode dated to $379 \mathrm{BC}$, related by Plutarch (Mor. 598D-E). Of course the

\footnotetext{
${ }^{19}$ E.g. the hero-cult of Tenes on Tenedos, see Plutarch (Mor. 297D). Cf. also the story by Apollodoros (Bibl. III.15.7) and Plutarch (Mor, 132F) of how Minos, in his grief, abolished the aulos and garland from the sacrifice to the Charites on Paros. On sorrow as a negation of music, see also Barker 1984: 69-71.
} 
trumpet as a military instrument is suitable for such warlike cults or cults to warrior heroes.

In the same category we must also count Athena, who is mentioned as the inventor of the trumpet in some sources, although other mythical figures can have the same role, e.g. Herakle's grandson Tyrrhenos ${ }^{14}$. In Argos the war goddess Athena was worshiped as Salpinx, i.e. as the war trumpet and is found with a trumpet on a red-figured vase from the Acropolis. ${ }^{15}$ That Athena's associate Nike, the goddess of victory, is also depicted with a trumpet is not surprising, as on a red-figured Etruscan vase ${ }^{16}$ or on coins minted for Demetrius Poliorketes around $289 \mathrm{BC}$. These coins have been brought into the discussion of Nike from Samothrake, now in the Louvre, which have been interpreted by some as carrying a salpinx.

Athena was also the patron of the city state of Athens and its organisation and functionaries, and her trumpet also suits that civic aspect of her. Trumpeters seem to have taken part in the great procession during the Panathenaeic festivals in honour of Athena, at least if the interpretation of Lehnsteadt (1970; 201, no. K84) of a red-figured cup from Saturina in Firenze $^{17}$ is right. These two trumpet functions, both the military and the civic, can be seen in the dedications to her:

"I, the trumpet that once poured forth the bloody notes of war in the battle and the sweet tune of peace, hang here, Pherenius, thy gift to the Titanian maid [i.e. Athena], resting my clamorous music". ${ }^{18}$

But the trumpet was also used in other cults. The earlier mentioned pylores of the Acropolis were responsible for the cult to Apollo Aigyeus at an altar by the gate. ${ }^{19}$ Trumpeters took part in the sacrifices at the official

\footnotetext{
${ }^{14}$ Tyrrhenos was the mythical ancestor to the Tyrrhenians. He was often taken to be a son of Herakles or Telephos (Paus. 2.21.3; Hygin. Fab. 274; Clem. Alex. Strom. 1.16). Among other mythological inventors are Archondas, an ally to the invading Herakleids (Eusth. ad Il. XVIII.220, Schol. Eur. Phoen. 1377, Souidas s.v. kodon), Maleos (Schol $I l$. XVIII, 220) and Pisaios, a Tyrrhenian from Tuscian Pisae (Plin. NH 7.56.201).

${ }^{15}$ Red-figured lekythos, Athen, Akrop. Mus. 2568, 1st half of 5th century BC (LIMC Athena no. 600). According to Pausanias (2.21.3) Hegeleos, Tyrrhenos' son, another inventor of the salpinx, was the one who established the cult of Athena Salpinx in Argos.

${ }^{15}$ Red-figured skyphos, Escherheim, coll. Haeberlin, 3rd quarter of the 4th century BC. Paquette 1984: 80 f. no. T11; Wegner 1949: pl. 26.

${ }^{17}$ Firenze, Arch. Mus. 81600. CVA Firenze IV, III,1, tav. 117, $118=$ Italia 38, tav. 1689, 1690; Paquette 1984: no. T10.

${ }^{18}$ Anth. Pal. VI, no. 195, by Antipater from Sidon, from the end of the 2nd cent. BC, translation W.R. Paton (Loeb ed.).

${ }^{19}$ For the trumpeters among the pylores, see Nordquist 1994.
} 


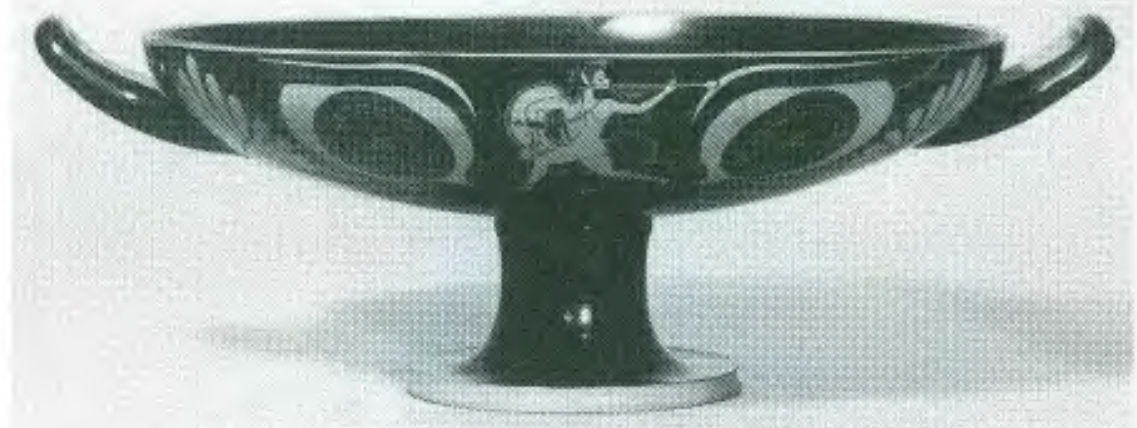

Fig. 1. Bilingual eye cup by Epiktetos, 520 BC: Silen blowing the salpinx. He is wearing the mouth-band, phorbeia, and carrying a shield and a jug. Courtesy British Museum, inv. E3.

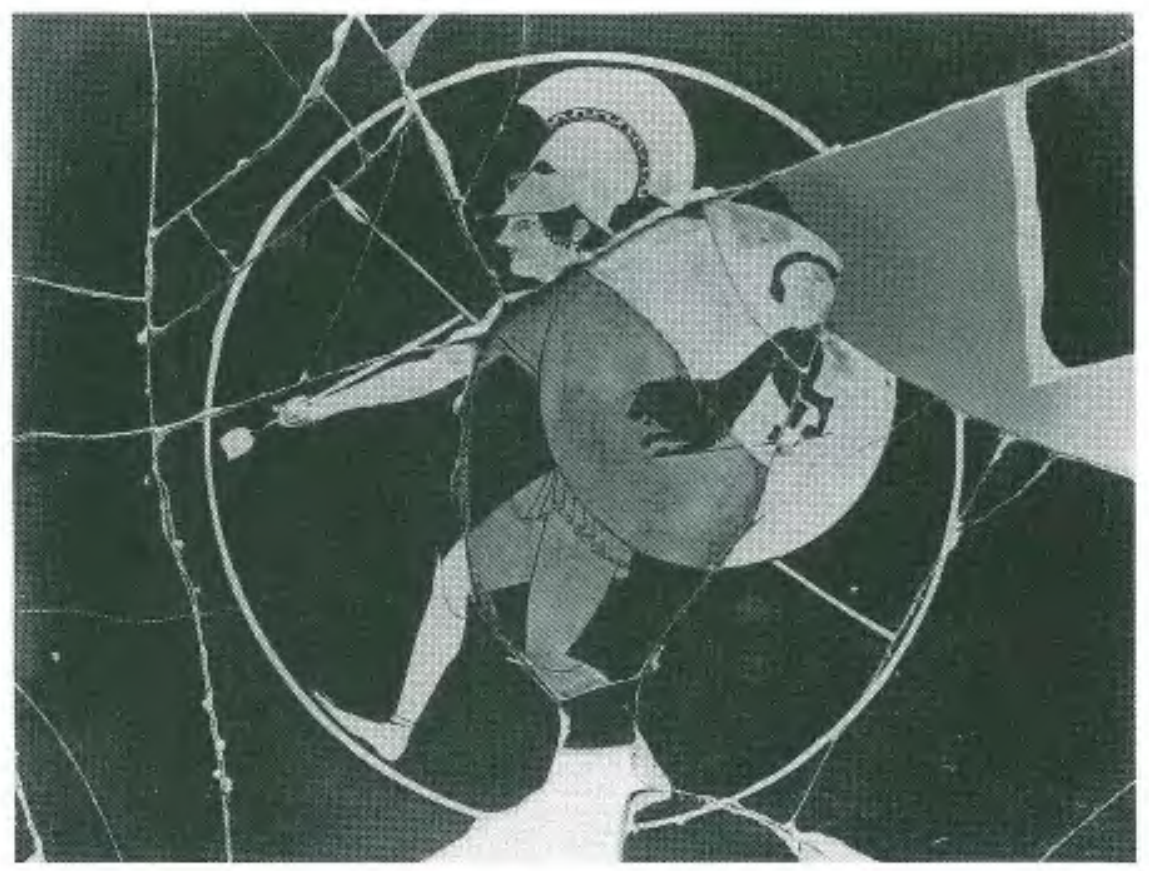

Fig. 2. Red-figured kylix by Oltos, c. 510 BC: Hoplite blowing a trumpet. Courtesy Antikensammlung, Staatliche Museen zu Berlin-Preussischer Kulturbesitz, inv. F2264. Photo by Rosa Mai. 


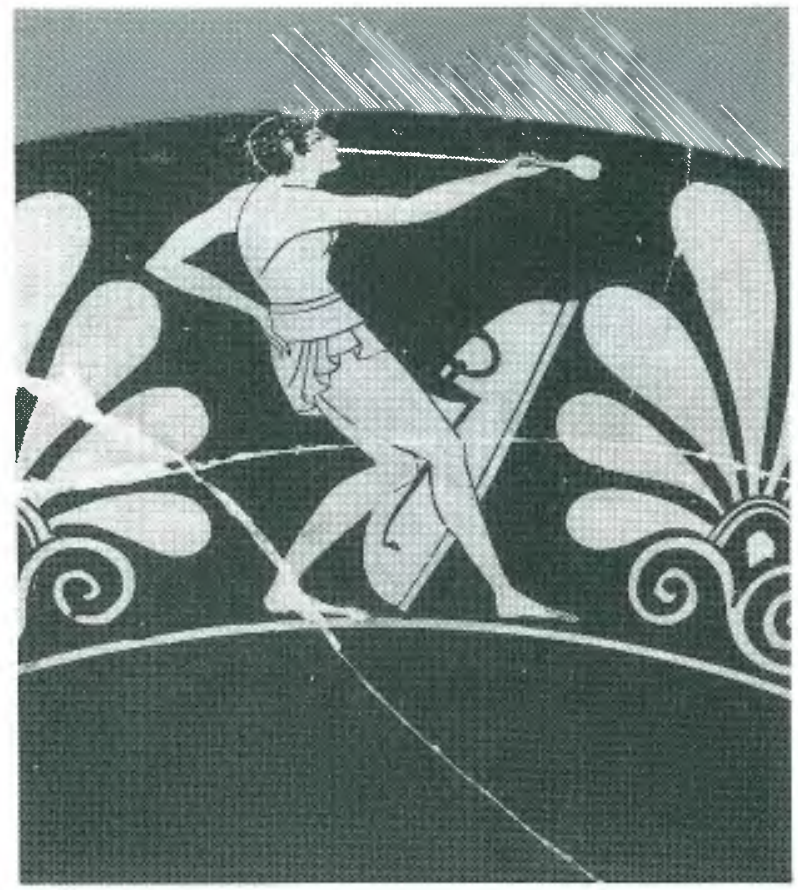

Fig. 3. Red-figured kylix by the

Scheurleer Painter, 510-500 BC:

Hoplite playing a trumpet. Courtesy the Louvre, Paris, inv. G 70.

Copyright photo R.M.N.

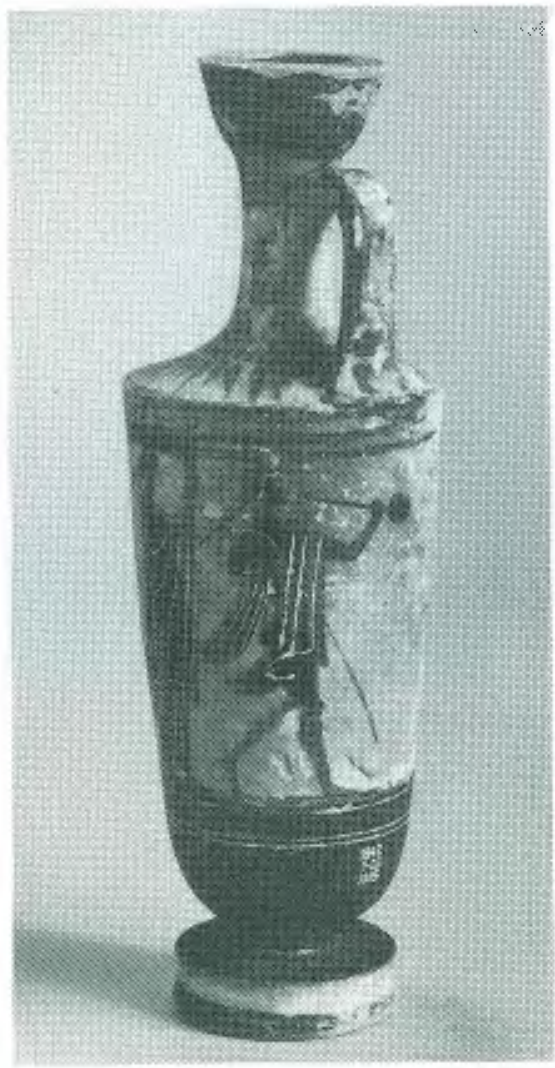

Fig. 4. Black-figured lekythos close to the Theseus Painter, c. $500 \mathrm{BC}$ : Trumpeter leading a procession. Courtesy British Museum, inv. B648. 
Athenian embassies, the theoriai, to important cult places, as seen from inscriptions from Delphi. At Argeios embassy in $97 \mathrm{BC}$ the trumpeter, who belonged to the administrative staff, not the musical or strategic, was a certain Aristomachos Damantos (Stephanis 1988: no. 358). One can wonder if he was the strategs' trumpeter, lent to the administration for the festivals.

In Boiotia the trumpet became common during games from the $5^{\text {th }}$ century onwards - the Herakleia at Thebes, already mentioned, is one such case. Later examples are the Mouseia in Thespiai from the $3^{\text {rd }}$ century BC (Roesch 1982: 495 f.; Frei 1900: table). At the festivals in honour of the smith god Hephaistos in Athens the trumpet was used, according to a cult regulation from about $420 \mathrm{BC}$, to call forward the sacrificial animals, in other words in a signalling function (Sokolowski 1969: no. 13). On a kylix by the Scheuleer painter in the Louvre, Fig. 3, the trumpet is played by a young man dressed in a hip-cloth. The shield beside him has as a shieldmark a tripod, perhaps a reference to the agones.

No Greek bronze trumpets have been found. Like other musicians and craftsmen, the trumpeters give their instruments to the sanctuaries, as votives (Anth. Pal. 6, nos. 46, 159, 194, 195). Votive figurines in the shape of trumpets or trumpeters are also found. At Salamis on Cyprus votive terracotta trumpets from the end of the $5^{\text {th }}$ and $4^{\text {th }}$ century BC appeared together with other types of votive figurines and were also found in graves (Chavane 1975: 205-211) and there are other, similar, examples in museums in Oxford and Nicosia (Paquette 1984: 74). Terracotta trumpets are also known from Egypt (Duchesne-Guillemin 1981: 291). A $157 \mathrm{~cm}$ long ivory trumpet of uncertain date now in Boston would, to judge from its length and material, probably have filled a ceremonial function (Caskey 1937; Sachs 1940: 145-148).

A more surprising use of the sacral trumpet is its appearance in the cult to Dionysos, the god of wine and inspiration. How strong its connection with Dionysos was can be understood from Plutarch's comment (Quaest. symp. IV , 6, 2) on the Jewish Tabernacle feast. He sees the fact that trumpets are played at this festival as a proof that the Jewish god can be identified with Dionysos and that Bacchich revelries were celebrated in the temple. ${ }^{20}$

The trumpet was used in the Dionysiac processions. During the Anthesteria Dionysos' ship cart was drawn through the street with trumpets

\footnotetext{
${ }^{20}$ Cf. Philo, Sept. 22. Trumpets are among the spoils of the temple on the Arch of Titus. Yarden 1991.
} 
leading the procession, a scene depicted on some black-figured vases (Frickenhaus 1912: 65 f.). In the great procession of Ptolemy II in Alexandria in the 270's BC, a couple of participants were dressed up as silenes, one as a herald and the other as a salpiktes, and led that part of the procession that was devoted to Dionysos (Rice 1983). As seen from these examples and as depicted on a black-figured lekythos in the British Museum $^{21}$, Fig. 4, the trumpeter led the processions, while other instruments, such as the auloi and the kithara, were to be found further along, usually in connection with the sacrificial animal (Nordquist 1992). Another iconographic connection between Dionysos and the trumpet is found on the the eye-cups, on which the exterior shows apotropaeic eyes. These, it has been suggested, notify a face mask of Dionysos, as argued by Ferrari (1986: w. further references). The interior may carry various figures, among them hoplite-trumpeters, as in several cups by Oltos $^{22}$ or a trumpeting silen, as on the eye cup by Epiktetos, Fig. 1.

Also to the anthesteria belonged the day called choai, when a trumpet gave the starting signal for the silent drinking contest according to Aristophanes (Ach. 1000f.). ${ }^{23}$ In contrast to other Greek symposia, at this occasion the participants sat alone and drank in silence, each from his own jug. According to the myth, the festival started when Orestes came to Athens after killing his mother, since the Athenians could not drive away someone seeking asylum, but neither wanted to take the risk of miasma from the murderer. In other words, the Choai was a feast with chthonic associations, a day of defilement (Burkert 1985: 238).

This chthonic association can also be found in other parts of the cult of Dionysos. Already in Aristophanes' The frogs Dionysos visits Hades, a visit that is the first more detailed description of Hades since the Odyssey. This chthonic Dionysos developed in the hellenistic period into Dionysos Zagreus, son of Zeus and Persephone, the Queen of the underworld, who was murdered by Hera but resurrected by Zeus with Semele as his fostermother. In the late hellenistic period Dionysos is the wine, dismembered and served for sacramental drinking. The myth of the dismemberment of

\footnotetext{
${ }^{21}$ BM B648, close to the Theseus Painter, c. 500 BC. Haspels 1936: 267, 14; Lehnsteadt 1970: 200 K76, Taf. 4:3; Frickenhaus 1912: 65 f., Beil. 1.4.

${ }^{22}$ Such cups by Oltos are e.g. the one in Bryn Mawr, inv. P-2155 (ARV ${ }^{2}, 1623,23$ bis) and the Vatican, Museo Gregoriano Etrusco inv. 34997 (Astarita 46) $\left(A R V^{2} 55,19\right)$, discussed by Ferrari 1986.

${ }^{23}$ The choe in the British Museum, depicting the satyr Kallinikos, victor in choedrinking may also be mentioned in this connection.
} 
the god may be as old as the Anthesteria festival according to Burkert (1985: 238 f., 298).

The chthonic Dionysos appears in the Bacchic mysteries and rituals related to the underworld (Burkert 1985: 290-295). At the mysteries at the Alkydian lake in the Argolid, which was considered to be one of the entrances to Hades, Dionysos went down to the underworld to fetch his dead mother. To summon him back to the earth surface, trumpets hidden in thyrsos wands were blown. At the same time a male sheep to the Pylaochos (Gate-Keeper) was sacrificed by being thrown into the lake (Plut. de Is. 364F, Mor. 671 E; cf. Paus. 2.36.7). On Roman Rhodes another loud wind instrument was used in the same function, namely the hydraulis or organ, according to an inscription from the $2^{\text {nd }}$ century $\mathrm{AD}$.

A chthonic aspect of the trumpet is also found in other regions of the eastern Mediterranean. It is said that the trumpet in Egypt was seen as an invention of the god of the underworld Osiris, and it was used in the cult of Osiris and in the death cult, as well as that of Ammon, and also for military purposes (Hickman 1961: 122; Duchesne-Guillemin 1981: 291). Manniche $(1991: 76,79)$ suggests that the two trumpets found in the grave of Tutankhamun may have had a function in connection with the king's resurrection in the underworld, i.e. in a role similar to that of the instrument in the mysteries at the Alkydian lake.

It is worth noting that the Greeks identified Osiris with Dionysos. In Greek Egypt, the trumpet became instead associated with the evil and redheaded Typhon, another deity connected with the underworld: He is said to be behind the eruptions of Etna. A salpinx sounded like the donkey, Typhon's sacrificial animal, and was therefore forbidden as unclean in GreekEgyptian towns, such as Busiris and Lycopolis, Plutarch states (De Is. 362F). It seems clear that the military trumpet had chthonic associations.

But trumpets were also played at merrier occasions with a humorous military or agonistic undercurrent. Satyrs attack the blood-red wine at supernatural symposia (Lissarague 1990: 70-74). On the vase paintings they fight chariot or foot races, sometimes watched by Dionysos himself, as on an oinochoe by the Altamura painter in Berlin ${ }^{24}$, or in the contest of chariots drawn by menads on a vase in Cambridge ${ }^{25}$. Such pictures were taken by Deubner (1956: $99,103,243 \mathrm{f}$.) to reflect the more general use of the

${ }^{24}$ Red-figured oinochoe, Berlin no. 1962, 33, Altamura Painter, c. 465-460 BC. $A R V^{2}$ 1660; Greifenhagen 1963: pl. 1-4; Paquette 1984: 76f. no. T1.

${ }^{25}$ Red-figured kylix, Cambridge 37.17, from Vulci, by the circle of the Nikosthenes Painter, end of 6th century BC. $A R V^{2} 133,4$; CVA Cambridge 2, pl. $6=$ Great Britain 11, pl. 515. 
salpinx at symposia, and he suggested that Aristophanes' description of the choai reflected the real use of the trumpet at festivities in the Thesmotheion. Trumpet signals at symposia are also mentioned elsewhere in Greek literature. The pseudo-Aristotelian treaty "On Acoustics" (803a), talks of soft trumpet playing as suitable for komasts, but mostly it is seen as a sign of the barbaric opulence of the Macedonian princes.

The Greek symposia have been much discussed during the past few years, as an essential part of male aristocratic Greek life. Scholars have stressed their social, political and religious function. The "drinking together" of the symposia made the men happy, strengthened the communal feeling and made it possible to reach the acme of human spiritual endeavour and thus gave inspiration to art, at the border between the supernatural, divine, sphere with its strong chaotic forces and the human sphere with its limitations. But the Greeks were aware of the danger of the uncontrolled consumption of both alcohol and feelings, which may lead to a point when this border is crossed, when the dionysiac rites open the way for strong, uncontrollable, forces that may lead to madness and violence (Lissarague 1990: 3-14). The mythology of Dionysos is rich in such dark sides and the legends of the introduction of the wine involve bloodshed. We can only remind ourselves of Ikarios or Penteus' horrible fate (Burkert 1985: 238, 241). The satyrs and menads, however, the supernatural entourage of Dionysos, can indulge in excessive orgies without risk, precisely because they are nonhuman.

The depictions of feasting sometimes also allude to violent or warlike activities, and blood and wine are often coupled. War scenes and dionysiac scenes are juxtaposed on the same vases, such as the kylix of the Nikosthenes painter at Castle Ashby with symposia on the exterior and an armed man with a trumpet in the interior, as a Thyrrhenic dancer. ${ }^{26}$ This is one ideal male sphere in one object: male friendship, loyalty and exhibitions of courage in symposia and war, wine and blood. In the same spirit silens with trumpet and shield are found on drinking vessels, as on the eye cup by Epiktetos in the British Museum, Fig. $6{ }^{27}$ showing how during the feasting the natural and supernatural forces attack sobriety and "the middle way" (Lissarague 1990: 70-76, 115-117).

\footnotetext{
${ }^{26}$ Red-figured kylix, Castle Ashby no. 57, by the Nikosthenes Painter, c. 520-510 BC. $A R V^{2}$ 455, 8; CVA Castle Ashby pl 35 = Great Britain 15, pl. 690; Paquette 1984: 82f. no. T15.

${ }^{27}$ Bilingual kylix by Epiktetos, London BM E3, 520 BC. $A R V^{2}$ 70:3; Paquette 1984: 73 , 78f. nos. $\mathrm{K} 1$ and T7.
} 
To this dionysiac sphere belong also other divinities who are concerned with man's sensibilities and emotions, such as the god of love, Eros. On a vase from Vienna winged Eros is depicted as blowing a salpinx, and behind him hangs a sword - another military attribute. ${ }^{28}$ Here the god of love is not the sweet, naughty little boy in later pictures, but depicted as a virile young man, as the Eros described by Hesiodos as a creative principle or a force of nature. Anacreon (413P) talks of Eros as a dangerous force, who kills you with his bronze axe (fr. 47). Eros sometimes also has a chthonic aspect and is occasionally found together with Thanatos, Death (Vermeule 1979: 157-162). Eros with the trumpet should be seen as a depiction of this mystical and potentially destructive force and as such connected with the dionysiac scenes.

But why does the trumpet appear in the cult of Dionysos, as well as in other Greek cults? What was its function? As we have seen the general function of the instrument was to signal a change of state, primarily between war and peace. It signalled attack and retreat, called silence or summoned. It marked the beginning and the end at the games, the symposia during choai, and at the opening and shutting of the doors of the Acropolis each morning and evening. It signalled the arrival of the holy procession. It warned and gave alarm. The trumpet signals were frightening symbols of war and danger, and were used in apotropaeic functions, not the least in contact with the underworld.

That loud instruments, often of metal, are used in apotropaeic functions at chthonic cults, funerals and in magic is common in many cultures. We find loud signals on wind instruments in many parts of the world, and percussion instruments, too, are frequently used in this role: drums, cymbals and bells. In Greece the sound of metal, especially bronze, was seen as apotropaeic and magic. ${ }^{29}$ Therefore metal idiphones were used in some cults, e.g. at Dodona (Cook 1902; Schatkin 1978: 161f.) and according to Apollodoros (FGrH 244F 110; Schatkin 1978: 162) the invocation of Kore at Eleusis was accompanied by the sound of a gong or cymbal played by a priest. At the death of Laconian kings metal was beaten (Herodt 6, 58, 1).

The trumpet, as a metal instrument also, had apotropaeic functions. This can be seen in, for example, Artemidoros' Dream book (1.56): To dream that

\footnotetext{
${ }^{28}$ Attic red-figured lekythos, Vienna University coll., inv. no. 561, from Gela, c. 480 BC. $A R V^{2}$ 447, 272; CVA Vienna 1, pl. 13: 2-3; LIMC Eros no. 664; cf. Nordquist 1995. The armed Eros also appears on other early red-figured vases, e.g. an amphora in Cab. Méd., Paris inv. 366, dated to 470-460 BC. LIMC Eros no. 723.

${ }^{29}$ See Schatkin 1978 and Gow's (1950: 43) comment on Theocritus, Idyll II, 36, with further examples.
} 
you are blowing a sacral trumpet is a good sign for people who want to find another person, or who have lost a slave or another member of the houshold, since even in war the trumpet collects that which has been dispersed, says Artemidoros. Through its loud sound, it finds things that have been hidden. It drives away illness, because it is made of bone and bronze, through which air is blown, without returning. It makes slaves and everybody under foreign power free from slavery, since it is the true instrument of the free. It is symptomatic that it means bad luck to dream of a broken trumpet, since such an instrument is not sacral, according to the Dream book, but an instrument of battle: that which the mouth says, which uses such an instrument, falls back in its own head. Therefore such a dream counsels people against fighting processes.

It may be of interest to compare this view with the Roman use of the sacral trumpet. The Etruscans, and later the Romans, used their trumpets in a much wider context than in Greece, in the funeral processions for men from the upper classes, as well as for military purposes and processions. The Romans had several forms of the trumpet, the lituus, the curved cornu and the straight $t u b a$, used in various contexts (Pollux, Onom. IV.86-87). Some of the Greek uses of the instrument were taken over. There are, for example, series of depictions of trumpets in dionysiac processions on Roman sarcophagoi.

During the Roman period sacral trumpeters, hierosalpiktes, became common in the cult. We have examples from the games, the festivals to Artemis and the curete collegia in Ephesos, as well as from hero-cults, such as the Theseia in Athens, all from the $2^{\text {nd }}$ century AD (Deubner 1956: 225f.). But with the increase in its use as a sacral instrument in the Roman period followed, not an extended or intensified symbolic value of the trumpet, but rather a trivialisation. The dichotomy of war and piece tended to become a topos without much content. Instead the military status of the trumpet was stressed. The aulos, the other war instrument, had since the $5^{\text {th }}$ century BC been considered as "low", even if it was perhaps the most widely used of all Greek musical instruments, in cult as well as in entertainment. It could be played by slaves as well as free, and by women something more unusual, but not unknown, for the salpinx. One example is the trumpeter Aglais, Megakleos' daughter, who worked in Alexandria during the Ptolemaeic period (Ath. 10.415a). ${ }^{30}$ The aulos became an in-

\footnotetext{
${ }^{30}$ Cf. also Aelian, Poik. Hist. 1.26; Pollux IV.89. Discussed by Stephanis (1988: no. 42) and Rice 1983: 48 n. 39.
} 
strument for professional musicians, i.e. artisans, and with that followed a correspondingly low social status.

The trumpet, by contrast, was as Artemidoros said (Dream book 4.56) the instrument of the the free. It had in Rome, as already said, long been used at aristocratic funerals. As an official war instrument it was also dignified enough to be played officially by free citizens and gentlemen. In Roman Ephesus the trumpeters often were winners in the Ephesian Olympic games, while the auletes were slaves. ${ }^{31}$ But in the Roman cult the salpinx functioned mostly as a signal instrument, or as a signal in the processions.

This can be compared to the salpinx functions in Greek civic and cultic life, which can be described as having the more practical role "to summon" and to of act as acoustic border marker. It measured the time, most clearly on the Acropolis. It divided a theatre performance in acts, the games in various events, the row of sacrificial animals in individual sacrifices, day from night, open from closed, silence from sound.

The most significant symbolic role is that of a signal between life and death, or between peace and war. It is this dichotomy that is so often stressed by the ancient sources, and that is behind many of the depictions, e.g. of the satyrs or Eros as the creative force with the instruments of death. In the choai and in the dionysiac cult in general, the trumpet signals marked the border between the civilised everyday human life and the advent of Dionysos with his mythical entourage and the dionysiac orgies, between sobriety and excesses, the border between our world and the world beyond.

\section{References Cited}

ARV $^{2}$ Beazley, John, Red Figured Vase Painters. Oxford: Clarendon Press, 1963. [2nd ed.]

Barker, Andrew (ed.)

1984 Greek Musical Writings; vol. 1: The Musician and his Art. Cambridge: Cambridge University Press.

Bélis, Annie

1984 Un noveau document musicales. Bulletin de Correspondance Hellenique 108: 99-109.

1986 La phorbeia. Bulletin de Correspondance Hellenique 110: 205-218.

\footnotetext{
${ }^{31}$ Sokolowski 1962: no. 121, discussed by Knibbe (1981: passim, esp. p. 78-95). In the inscriptions salpiktes both from Athens and from Ephesos are usually listed with name and demotikon, sometimes patronymikon from the hellenistic period onwards. The auletes, however, are listed before the hierosalpiktes, since their is the older function.
} 


\section{Burkert, Walter}

1985 Greek Religion. Oxford: Blackwell.

Caskey, L. D.

1937 Recent acquisitions of the Museum of Fine Arts, Boston. American Journal of Archaeology 41: 525-527.

Chavane, Marie-Jose

1975 Salamine de Chypre VI. Les petits objets. Paris: Boccard.

Cook, A. B.

1902 The Gong at Dodona. Journal of Hellenic Studies 22: 5-28.

CVA Corpus Vasorum Antiquarum

Deubner, Lud.

1956 Attische Feste. Berlin: Akademie Verlag. [1932]

Duchesne-Guillemin, Marcelle

1981 Music in ancient Mesopotamia and Egypt. World Archaeology 12: 287-297.

Eckstein, Felix

1988 Trompeter in Olympia. In: Michael Wissemann (ed.), Roma renascens. Beiträge zur Spätantike und Rezeptionsgeschichte. Ilona Opelt von ihren Freunden und Schülern zum 9.7.1988 in Verehrung gewidmet; pp. 52-64. Frankfurt: Peter Lang.

Eitrem, S.

1920 Beiträge zur griechischen religionsgeschichte, vol. 3. Kristiania. (Skrifter utgivna av Videnskabs-Selskabets, Hist.-Filos. klasse 1919: 2).

Ferrari, Gloria

1986 Eye-cup. Revue Archéologique 1986/1: 5-20.

Frei, J.

1900 De certaminibus thymelicis. Basel: Birkhaeuser.

Frickenhaus, A.

1912 Der Schiffskarren des Dionysos in Athen. Jahrbuch des Deutschen Institut 27: 61-79.

Geagan, Daniel J.

1967 The Athenian Constitution after Sulla. Princeton: American School of Classical Studies at Athens. (Hesperia. Supplement, 12)

Gow, A.S. F.

1950 Theocritos; vol. 2: Commentary, appendix, indexes, and plates. Cambridge: Cambridge University Press.

Greifenhagen, Adolf

1963 Ein Satyrspiel des Aischylos. Berlin: de Gruyter. (Winckelmannprogramm der Archäologischen Gesellschaft zu Berlin, 118)

Guarducci, Margherita

1942 Due iscrizione e una preunta pestilenza di Gortyna. Epigraphica 4: 177-190, esp. 185-186.

Haldane, J. A.

1966 Musical instruments in Greek worship. Greece and Rome 13: 98-107.

Haspels, Emelie

1936 Attic black-figured lekythoi. Paris: Boccard (École francaise d'Athènes. Travaux et mémoires, 4). 
Hickmann, Hans

1946 La trompette dans l'Egypte ancienne. Cairo: L'Institut francais d'archéologie orientale. (Supplement aux Annnales du Service des antiquites de l'Egypte, 1)

1961 Ägypten. Leipzig: VEB Deutscher Verlag für Musik. (Musikgeschichte in Bildern, 2, 1)

\section{Knibbe, Dieter}

1981 Der Staatsmarkt. Die Inschriften des Prytaneions. Die Kureteninschriften und sonstige religiöse Texte. Wien: Verlag der Österreichischen Akademie der Wissenschaften (Forschungen in Ephesos 9, 1, 1)

Krenz, Peter

1991 The salpinx in Greek warfare. In: Victor Davis Hanson (ed.), Hoplites. The Classical Greek Battle Experience; pp. 110-120. London: Routledge.

Lehnsteadt, $\mathbf{K}$.

1970 Prozessionsdarstellungen auf attischen Vasen. Bamberg.

LIMC Lexicon Iconographicum Mythologiae Classicae. Zürich: Artemis.

Lissarague, $\mathrm{F}$.

1990 The Aesthetics of the Greek Banquet. Images of Wine and Ritual. Princeton: Princeton University Press.

Manniche, Lise

1991 Music and Musicians in Ancient Egypt. London: British Museum.

Nilss on, Martin P.

1906 Griechische Feste von religiöser Bedeutung. Leipzig: Teubner.

1916 Die Prozessionstypen im griechischen Kult. Jahrbuch des deutschen Instituts 31: 309-339.

Nordquist, Gullög C.

1992 Instrumental music in representations of Greek cult. In: Robin Hägg (ed.), The Iconography of Greek Cult in the Archaic and Classical Periods. Proceedings of the First International Seminar on Ancient Greek Cult, organised by the Swedish Institute at Athens and the European Cultural Centre of Delphi, Delphi 16-18 November 1990; pp. 143-168. Athènes: Centre d'Etude de la Religion Grecque Antique. (Kernos. Supplément, 1).

1994 Some Notes on Musicians in Greek cult. In: Robin Hägg (ed.), Ancient Greek Cult Practice from the Epigraphical Evidence. Proceedings of the Second International Seminar on Ancient Greek Cult, organized by the Swedish Institute at Athens, 22-24 November 1991; pp. 81-93. Stockholm: Paul Åström. (Skrifter utgivna av Svenska institutet: Athen. Series in 8:0,13)

1991 The Salpinx as an Instrument of Eros and Dionysos, Imago Musicae 8: 61-72. [cop. 1995] .

Paquette, Daniel

1984 L'instrument de musique dans la ceramique de la Grèce antique. Paris: Boccard. (Publications de la Bibliothèque Salomon Reinach, 4) 
Rice, E. E.

1983 The Grand Procession of Ptolemy Philadelphus. Oxford. Oxford University Press.

Ridder, A. de

1902 Catalogue des vase peints de la Bibliotheque National. Paris: Thorin $\&$ Fils.

Roesch, Paul

1982 Études béotiennes. Paris: Boccard

Sachs, Curt

1940 History of musical instruments, New York: W. W. Norton \& Co..

Schatkin, Margaret A.

1978 Idiophones of the ancient world. Description, terminology, geographical distribution, functions. Jahrbuch für Antike und Christentum 21: 147-172.

Sokolowski, Franciszek

1962 Lois sacrées des cités grecques. Supplément. Paris: Boccard. (Travaux et memoires des anciens membres étrangers de l'Ecole française d'Athènes, 11)

1969 Lois sacrées des cités grecque. Paris: Boccard. (Travaux et memoires des anciens membres étrangers de l'Ecole française d'Athènes, 18)

Stephanis, I. E.

1988 Dionysiakoi technitai. Symboles stin prosopographia tou theatrou kai tes mousikis ton archaeion ellenon. Heraklion: Panepistemiakes ekdoseis Kritis.

Vermeule, Emily

1979 Aspects of Death in Early Greek Art and Poetry. Berkeley: University of California Press. (Sather Classical Lectures, 46)

Wegner, Max

1949 Griechenland. Leipzig: Deutscher Verlag für Musik. (Musikgeschichte in Bildern, 2, 4)

West, M. L.

1992 Ancient Greek Music. Oxford: Clarendon Press.

Yarden, Leon

1991 The Spoils of Jerusalem on the Arch of Titus. A Re-Investigation. Stockholm: Svenska Institutet i Rom. (Skrifter utgivna av Svenska Institutet i Rom, 16) 